\title{
Trophic-level determinants of biomass accumulation in marine ecosystems
}

\author{
Fabio Pranovi ${ }^{1, *}$, Jason Link ${ }^{2}$, Caihong Fu ${ }^{3}$, Adam M. Cook ${ }^{4}$, Hui Liu ${ }^{2}$, \\ Sarah Gaichas ${ }^{5}$, Kevin D. Friedland ${ }^{6}$, Kjell Rong Utne ${ }^{7}$, Hugues P. Benoît ${ }^{8}$ \\ ${ }^{1}$ Department of Environmental Sciences, Informatics and Statistics, University Ca' Foscari, Venice, Castello 2737/b 30122, \\ Venice, Italy \\ ${ }^{2}$ NOAA, National Marine Fisheries Service, Northeast Fisheries Science Center, Woods Hole, Massachusetts 02543, USA \\ ${ }^{3}$ Pacific Biological Station, Nanaimo, British Columbia V9T 6N7, Canada \\ ${ }^{4}$ Fisheries and Oceans Canada, Bedford Institute of Oceanography, Dartmouth, Nova Scotia B2Y 4A2, Canada \\ ${ }^{5}$ NOAA, National Marine Fisheries Service, Alaska Fisheries Science Center, Seattle, Washington 98115, USA \\ ${ }^{6}$ NOAA, National Marine Fisheries Service, Northeast Fisheries Science Center, Narragansett, Rhode Island 02882, USA \\ ${ }^{7}$ Institute of Marine Research, Nordnesgt 33, 5085 Bergen, Norway \\ ${ }^{8}$ Gulf Fisheries Centre, Fisheries and Oceans Canada, Moncton, New Brunswick E1C 9B6, Canada
}

\begin{abstract}
Metrics representative of key ecosystem processes are required for monitoring and understanding system dynamics, as a function of ecosystem-based fisheries management (EBFM). Useful properties of such indicators should include the ability to capture the range of variation in ecosystem responses to a range of pressures, including anthropogenic (e.g. exploitation pressures) and environmental (e.g. climate pressures), as well as indirect effects (e.g. those related to food web processes). Examining modifications in ecological processes induced by structural changes, however, requires caution because of the inherent uncertainty, long feedback times, and highly nonlinear ecosystem responses to external perturbations. Yet trophodynamic indicators are able to capture important changes in marine ecosystem function as community structures have been altered. One promising family of such metrics explores the changing biomass accumulation in the middle trophic levels (TLs) of marine ecosystems. Here we compared cumulative biomass curves across TLs for a range of northern hemisphere temperate and boreal ecosystems. Our results confirm that sigmoidal patterns are consistent across different ecosystems and, on a broad scale, can be used to detect factors that most influence shifts in the cumulative biomass-TL curves. We conclude that the sigmoidal relationship of biomass accumulation curves over TLs could be another possible indicator useful for the implementation of EBFM.
\end{abstract}

KEY WORDS: Marine ecosystems · Fishing impact - Trophodynamic indicators · Trophic level · Cumulative biomass curve $\cdot$ Environmental factors

\section{INTRODUCTION}

Implementation of ecosystem-based fisheries management (EBFM) requires information pertaining to the structure and function of the biotic communities within an ecosystem. To use such information, metrics representative of key processes are required, as is establishing thresholds for them from which management actions can be triggered. There is a growing body of work on indicators germane to fishing pressures and responses (Degnbol \& Jarre 2004, Cury \& Christensen 2005, Link 2005, Rice \& Rochet 2005, Bundy et al. 2010, Coll et al. 2010, Link et al. 2010a) as well as the establishment of indicators and thresh- 
olds that delineate ecosystem overfishing (EOF; Tudela et al. 2005, Coll et al. 2008, 2010, Libralato et al. 2008, Link et al. 2010a, Shin et al. 2010a). Useful properties of such indicators include being responsive to variation in a diversity of specific pressures including anthropogenic (e.g. exploitation pressure), environmental (e.g. climate), and trophodynamic (ecological interactions). This 'triad' of drivers (Link et al. 2012, this Theme Section [TS]) can significantly impact the production of fisheries in an ecosystem, and developing suites of metrics that would indicate when such production was being altered is valuable.

Among this triad of drivers, 2 are external to a system (anthropogenic and environmental) and can have a strong influence over the third driver, the trophodynamic features of an ecosystem. Often these impacts result from changes to the structure of biotic communities in an ecosystem. Examining modifications in ecological processes induced by structural changes, as caused by these external perturbations, requires caution because of the inherent uncertainty, long feedback times, and nonlinearity of ecosystem responses to external perturbations (Holling et al. 1995). A comparative approach is needed to establish what are normal and what are extreme fluctuations in marine ecosystems, and to establish ranges of thresholds in response to these fluctuations such that they are useful for EBFM (Piatt et al. 2007, Murawski et al. 2009, Link et al. 2010b). Ideally, such a comparative approach should encompass a multi-species, multiregion, and multi-trophic level set of conditions.

Since Odum \& Heald (1975) described fractional trophic levels (TLs), the use of an energetic context for evaluating ecosystem function has been widely developed. Trophodynamic studies have elucidated important responses in marine ecosystem functioning as community structure has been altered (e.g. Pitcher \& Cochrane 2002, Coll et al. 2010, Shannon et al. 2010, Shin et al. 2010b). Many of these papers have specifically examined such responses with respect to the impacts of fishing, serving as first attempts to delineate EOF (e.g. Pauly et al. 2000, Gascuel et al. 2005, 2008, Coll et al. 2008, Libralato et al. 2008). These trophodynamic measures show notable promise of being robust EOF measures that capture changes to the dynamics of the major processes constituting ecosystem function.

In this trophodynamic context, accumulation of biomass has been documented for many marine food webs, with the middle TLs exhibiting the largest increase in cumulative biomass for a system (Gascuel et al. 2005, Link et al. 2009a). Changes to this accumulation may reflect shifts in ecosystem structure and function, as well as represent important considerations for management thresholds. How robust and consistent this accumulation of biomass is as a general feature of marine ecosystems is unknown. Here we compared such cumulative biomass curves across TLs for a range of northern hemisphere temperate and boreal ecosystems. Our objectives were to evaluate the consistency of this suspected pattern across different ecosystems and, if the pattern held, to examine those broad-scale factors that most influence temporal shifts in the cumulative biomass-TL (cumB-TL) curves.

\section{MATERIALS AND METHODS}

\section{Ecosystems and data sets}

The key characteristics of the 10 compared ecosystems, in terms of type of system, main changes over the time, and key environmental factors, are listed in Table 1, along with their abbreviations, and a map of their location is given in Fig. 2 of Link et al. (2012). Annual biomass for each species is contained in the CAMEO database (Link et al. 2010b), and the species included in the calculation for each ecosystem are listed in Table 2. It is worth noting that for some ecosystems, the database comprises not just fish species, but also different groups of invertebrates. Biomass estimates were obtained from stock assessments when available or from research surveys. Stock assessment estimates of biomass typically corresponded to the exploitable portion of total biomass, assuming knife-edge recruitment. Swept-area estimates of survey biomass were expanded to the total area of the ecosystem and were corrected for catchability when possible (for major details, refer to Link et al. 2010b).

\section{Trophic spectra}

The trophic spectra analysis, i.e. the distribution of an ecological property, such as biomass, along TLs, has been proposed as an indicator to assess the effect of fishing activities on the ecosystem structure (Gascuel et al. 2005). Studying the trophic structure of fish communities (but also of taxonomically larger biological communities) involves species aggregation based on trophic similarities (Bozec et al. 2005). As highlighted by Libralato \& Solidoro (2010), a possible critical issue in the trophic spectra analysis is related to the method used to distribute the biomass value of 
each species/group over a continuum of TLs. Due to variability in species diet that generally changes during life history (e.g. Jennings et al. 2002a) and the lack of dietary information for many fish species, the trophic position of a species is better characterized by a range of fractional TLs rather than a single value.

Table 1. Key characteristics of 10 ecosystems; for references about ecosystem changes over time and key environmental influences, see Fu et al. (2012, this Theme Section, their supplementary material). References reported here refer to EwE models.TL: trophic level

\begin{tabular}{|ll}
\hline Ecosystem (Source) & Important changes \\
\hline Transitional between Arctic and sub Arctic \\
$\begin{array}{ll}\text { EBS: Eastern Bering Sea, } & \text { A majority of commercial fishery tonnage } \\
\text { USA (Aydin et al. 2007) } & \text { depends on walleye pollock production, which } \\
& \text { in turn is hypothesized to be closely tied to } \\
& \text { climate and sea ice dynamics. A recent stretch } \\
& \text { of anomalously warm years with early ice } \\
& \text { retreat resulted in low zooplankton biomass } \\
& \text { and poor pollock production 2001-2005, while } \\
& \text { cooler years with late ice retreat 2007-2010 } \\
& \text { resulted in higher zooplankton biomass, } \\
& \text { improved pollock production. }\end{array}$
\end{tabular}

\section{Downwelling}

GOA: Gulf of Alaska

(Aydin et al. 2007)

HS: Hecate Strait, Canada (Ainsworth et al. 2002)

\section{Temperate-boreal}

NL: Newfoundland \& Labrador

(Pitcher et al. 2002)
Large-scale groundfish and crab fishing began in 1960; groundfish fishing continues to the present, while crab and shrimp fisheries declined around 1980 and never recovered. A major change in community composition at multiple TLs was observed around 1977 and has been attributed to a climate regime shift. However, physical mechanisms driving dynamics have proven elusive in the GOA. Arrowtooth flounder populations have increased since the 1960s, while pollock peaked and declined in that time.

Groundfish fisheries were introduced in the 1970s. Most groundfish species of limited commercial value that are caught primarily as bycatch in groundfish fisheries showed an increasing trend over the entire time series with an approximate 4 -fold increase in biomass. Two other groups (12 groundfish species) showed an initial period of increase, followed by a decline to the late 1990s, and an increase in the early 2000s. A final group that included Pacific cod and spiny dogfish showed a downward trend throughout the time series. Trends in biomass of commercially important groundfish species generally correspond to trends in fishing effort and a continuing increase in primary and secondary production.

The 1985-1993 fish collapses led to a fishing moratorium in 1992. At the same time, other fisheries (notably crab) are experiencing record yields.
Key environmental influences

This region is influenced by the El NiñoSouthern Oscillation (ENSO) and the Arctic Oscillation. These climate drivers combined with local conditions influence the timing of ice formation and retreat on the Bering Sea shelf, which is critical to setting up conditions for biological productivity across most TLs. Warm conditions associated with early ice retreat and late water column stratification favor later zooplankton blooms and more pelagic production, while in cold years with late ice retreat, stratification happens immediately, promoting blooms that sink to the benthic energy food web.

The Pacific Decadal Oscillation is an atmosphere-ocean pattern observed across the North Pacific and linked to zooplankton and salmon productivity in the oceanic GOA. Local weather patterns are also influenced by ENSO. Locally varying conditions lead to complex and dynamic influences in various regions of the continental shelf.

Enrichment: wind-driven upwelling (weakening downwelling), estuarine flow of FW runoff, tidal and wind mixing. Initiation: shallow banks limit depth of mixing (localized effect). Southerly winds dominate in winter; conversely, in summer, relaxation of downwelling winds produces a surface offshore flow and a deep onshore flow.

Characterized by a wide and relatively shallow continental shelf transected in places by deeper trenches. Ocean circulation is dominated by the southerly flowing and cold Labrador current and its interaction with the warm Gulf Stream. 
Table 1 (continued)

\begin{tabular}{|c|c|}
\hline Ecosystem (Source) & Important changes \\
\hline $\begin{array}{l}\text { SGOSL: Southern Gulf of } \\
\text { Saint Lawrence } \\
\text { (Morissette et al. 2003) }\end{array}$ & $\begin{array}{l}\text { Since the 1950s, exploitation of groundfish has } \\
\text { been intense. In the early 1990s, the cod stock } \\
\text { collapsed, other groundfish species experi- } \\
\text { enced serious declines, and the ecosystem } \\
\text { switched from one dominated by demersal fish } \\
\text { to one dominated by forage species such as } \\
\text { sand lance, herring, and invertebrates such as } \\
\text { shrimp, snow crab, and clams. There have been } \\
\text { significant fishing impacts with decreases in } \\
\text { fish size, TL, and proportion of predatory fish. }\end{array}$ \\
\hline \multicolumn{2}{|l|}{ Temperate } \\
\hline $\begin{array}{l}\text { ESS: Eastern Scotian Shelf } \\
\text { (Bundy 2005) }\end{array}$ & $\begin{array}{l}\text { In the early 1990s, the cod stock collapsed, } \\
\text { other groundfish species experienced serious } \\
\text { declines, and the ecosystem switched from one } \\
\text { dominated by demersal fish to one dominated } \\
\text { by forage species such as sand lance, herring, } \\
\text { and invertebrates such as shrimp, snow crab, } \\
\text { and clams. In addition, the grey seal population } \\
\text { increased exponentially since the early } 1970 \text { s. } \\
\text { There have been significant fishing impacts } \\
\text { with decreases in fish size, TL, and proportion } \\
\text { of predatory fish. }\end{array}$ \\
\hline
\end{tabular}

WSS: Western Scotian Shelf This system has seen changes in species (Araújo \& Bundy 2011)

GB: Georges Bank

(Link et al. 2006, 2008)

GOM: Gulf of Maine

(Link et al. 2006, 2008) composition, with reductions in the biomass of groundfish and flatfish and increases in some invertebrates. These changes have been accompanied by reductions in mean weight and length at age for some key commercial stock. These changes are not as severe as those observed on the ESS.

The system changed from one dominated by flatfish and gadids to one dominated by small pelagics and elasmobranchs. Also, the community shifted from demersal to pelagic. The major perturbations were the arrival and subsequent departure of the distant water (international) fleets with an estimated 50\% decline in fish biomass during this time period; and the 200 mile $(\sim 320 \mathrm{~km})$ limit extended jurisdiction in 1977 combined with modernization and increased capacity of the domestic fleet-reducing groundfish to historically low levels. Recently there has also been a documented shift in some fish populations, likely due to change in temperature. Zooplankton composition shifted between the 1980s and 1990s coinciding with a major change in surface layer salinity.

As in GB above
Key environmental influences

The Gulf of St. Lawrence is considered an inland sea. With a drainage basin that includes the Great Lakes, the gulf receives more than half of the freshwater inputs from the Atlantic coast of North America. The SGOSL has the farthest regular annual extension of sea ice in the north Atlantic during winter, yet largely the warmest surface water temperatures in Atlantic Canada during the summer.

The hydrographic environment of the Scotian Shelf is governed largely by its location near the confluence of 3 major currents, a Shelf current, which brings cool fresh water primarily from the Gulf of St. Lawrence; the Labrador Current, which brings cold fresh water from the north along the edge of the shelf; and the Gulf Stream, which brings warm salty water from the south. Shelf bottom is also an important factor affecting the hydrographic environment.

The WSS is subject to a similar hydrographic environment to the ESS. However, it is more subject to the influence of the Gulf Stream, which brings warm salty water from the south.

Offshore upwelling along the shelf-slope break, vigorous tidal mixing, and the generally clockwise pattern of its currents concentrates nutrients on GB, making it highly productive. Periods of stratification can occur seasonally and in localized areas, which can temporarily interrupt the nutrient cycle.

Movement of deep slope water into the GOM through the northeast channel which carries a steady supply of nutrients, which is interrupted by summer stratification. Nutrient-poor Labrador Shelf water is occasionally transported from the north by intense negative North Atlantic Oscillation (NAO), and intrusion of fresh water from ice melting in the Gulf of St. Lawrence and Arctic has recently occurred. 
Table 1 (continued)

\begin{tabular}{|c|c|c|}
\hline Ecosystem (Source) & Important changes & Key environmental influences \\
\hline \multicolumn{3}{|l|}{ Upwelling } \\
\hline $\begin{array}{l}\text { BSNS: Barents Sea/ } \\
\text { Norwegian Sea } \\
\text { (Gaichas et al. 2009, } \\
\text { Skaret \& Pitcher 2012) }\end{array}$ & $\begin{array}{l}\text { The herring stock collapsed in the late 1960s } \\
\text { and did not recover fully until the 1990s. } \\
\text { There have been } 3 \text { collapses of the capelin } \\
\text { stock }(1985,1993,2003) \text {, all followed by a rapid } \\
\text { recovery of the stock. There was increased } \\
\text { abundance of pelagic fish in the Norwegian } \\
\text { Sea from } 1995 \text { to } 2006 \text { concurring with an } \\
\text { increase in water temperature. }\end{array}$ & $\begin{array}{l}\text { The NAO determines the inflow strength } \\
\text { of Atlantic water, which affects the water } \\
\text { temperature and salinity. This affects the } \\
\text { amount of ice in the Barents Sea. }\end{array}$ \\
\hline
\end{tabular}

Table 2. Species included in each ecosystem (abbreviations as in Table 1). NS: species not specified

\begin{tabular}{|c|c|c|c|c|c|c|c|c|c|c|c|}
\hline & EBS & GOA & HS & & NL & SGOSL & ESS & WSS & GOM & GB & BSNS \\
\hline Pacific Ocean & & & & Atlantic Ocean & & & & & & & \\
\hline Alaska plaice & $\mathrm{X}$ & $\mathrm{X}$ & & Aesop shrimp & $\mathrm{X}$ & & & & & & \\
\hline Alaska skate & $\mathrm{X}$ & & & Alewife & & $\mathrm{X}$ & $\mathrm{X}$ & & & & \\
\hline Arrowtooth flounder & $\mathrm{X}$ & $\mathrm{X}$ & $\mathrm{X}$ & American lobster & & $\mathrm{X}$ & $\mathrm{X}$ & $\mathrm{X}$ & & & \\
\hline Atka mackerel & $\mathrm{X}$ & $\mathrm{X}$ & & American plaice & $\mathrm{X}$ & $\mathrm{X}$ & $\mathrm{X}$ & & $\mathrm{X}$ & $\mathrm{X}$ & \\
\hline Big skate & & $\mathrm{X}$ & & Arctic cod & $\mathrm{X}$ & & & & & & \\
\hline Bivalves (NS) & $\mathrm{X}$ & & & Atlantic argentine & & & $\mathrm{X}$ & & & & \\
\hline Bocaccio & & & $\mathrm{X}$ & Atlantic butterfish & & & & & $\mathrm{X}$ & $\mathrm{X}$ & \\
\hline Copepods (NS) & $\mathrm{X}$ & & & Atlantic cod & $\mathrm{X}$ & $\mathrm{X}$ & $\mathrm{X}$ & $\mathrm{X}$ & $\mathrm{X}$ & $\mathrm{X}$ & $\mathrm{X}$ \\
\hline Crabs other (NS) & $\mathrm{X}$ & & & Atlantic hagfish & & & $\mathrm{X}$ & $\mathrm{X}$ & & & \\
\hline Crustaceans other (NS) & $\mathrm{X}$ & & & Atlantic halibut & $\mathrm{X}$ & $\mathrm{X}$ & $\mathrm{X}$ & & $\mathrm{X}$ & $\mathrm{X}$ & \\
\hline Curlfin sole & & & $\mathrm{X}$ & Atlantic herring & $\mathrm{X}$ & $\mathrm{X}$ & & $\mathrm{X}$ & $\mathrm{X}$ & $\mathrm{X}$ & $\mathrm{X}$ \\
\hline Dover sole & $\mathrm{X}$ & $\mathrm{X}$ & $\mathrm{X}$ & Atlantic mackerel & & & $\mathrm{X}$ & $\mathrm{X}$ & $\mathrm{X}$ & $\mathrm{X}$ & $\mathrm{X}$ \\
\hline Dusky rockfish & $\mathrm{X}$ & $\mathrm{X}$ & & Atlantic redfishes (NS) & $\mathrm{X}$ & $\mathrm{X}$ & $\mathrm{X}$ & $\mathrm{X}$ & $\mathrm{X}$ & $\mathrm{X}$ & \\
\hline English sole & & & $\mathrm{X}$ & Atlantic tomcod & & & & $\mathrm{X}$ & & & \\
\hline Eulachon & $\mathrm{X}$ & $\mathrm{X}$ & $\mathrm{X}$ & Atlantic wolffish & $\mathrm{X}$ & $\mathrm{X}$ & & & $\mathrm{X}$ & $\mathrm{X}$ & \\
\hline Fish other (NS) & $\mathrm{X}$ & & & Barndoor skate & & & & $\mathrm{X}$ & & & \\
\hline Flathead sole & $\mathrm{X}$ & $\mathrm{X}$ & $\mathrm{X}$ & Blue hake & $\mathrm{X}$ & & & & & & \\
\hline Forage fishes other (NS) & $\mathrm{X}$ & $\mathrm{X}$ & & Blue whiting & & & & & & & $\mathrm{X}$ \\
\hline Gelatinous filter feeders (NS) & $\mathrm{X}$ & & & Common alligatorfish & $\mathrm{X}$ & & & & & & \\
\hline Greenlings (NS) & $\mathrm{X}$ & $\mathrm{X}$ & & Common grenadier & $\mathrm{X}$ & & & & & & \\
\hline Grenadiers (NS) & & $\mathrm{X}$ & & Cunner & & $\mathrm{X}$ & & & & & \\
\hline Hermit crabs (NS) & $\mathrm{X}$ & & & Cusk & & & $\mathrm{X}$ & $\mathrm{X}$ & & & \\
\hline Kamchatka flounder & $\mathrm{X}$ & & & Daubed shanny & $\mathrm{X}$ & & & & & & \\
\hline King crab & $\mathrm{X}$ & & & Fourline snakeblenny & $\mathrm{X}$ & & & & & & \\
\hline Large sculpins (NS) & $\mathrm{X}$ & $\mathrm{X}$ & & Fourspot flounder & & & & & $\mathrm{X}$ & $\mathrm{X}$ & \\
\hline Lingcod & & & $\mathrm{X}$ & Goosefish & & & $\mathrm{X}$ & $\mathrm{X}$ & $\mathrm{X}$ & $\mathrm{X}$ & \\
\hline Longnose skate & & $\mathrm{X}$ & & Greenland cod & & $\mathrm{X}$ & & & & & \\
\hline Northern rock sole & $\mathrm{X}$ & $\mathrm{X}$ & & Haddock & $\mathrm{X}$ & $\mathrm{X}$ & $\mathrm{X}$ & $\mathrm{X}$ & $\mathrm{X}$ & $\mathrm{X}$ & $\mathrm{X}$ \\
\hline Northern rockfish & $\mathrm{X}$ & $\mathrm{X}$ & & Halibut & & & & $\mathrm{X}$ & & & \\
\hline Pacific cod & $\mathrm{X}$ & $\mathrm{X}$ & $\mathrm{X}$ & Jonah crab & & & $\mathrm{X}$ & & & & \\
\hline Pacific halibut & $\mathrm{X}$ & $\mathrm{X}$ & $\mathrm{X}$ & Longfin hake & $\mathrm{X}$ & $\mathrm{X}$ & & & & & \\
\hline Pacific herring & $\mathrm{X}$ & $\mathrm{X}$ & $\mathrm{X}$ & Longfin squid & & & & & $\mathrm{X}$ & $\mathrm{X}$ & \\
\hline Pacific ocean perch & $\mathrm{X}$ & $\mathrm{X}$ & & Longhorn sculpin & & $\mathrm{X}$ & & & & & \\
\hline Pacific salmon & $\mathrm{X}$ & $\mathrm{X}$ & & Longnose eel & $\mathrm{X}$ & & & & & & \\
\hline Pacific sand lance & $\mathrm{X}$ & $\mathrm{X}$ & & Lumpfish & $\mathrm{X}$ & & $\mathrm{X}$ & $\mathrm{X}$ & & & \\
\hline Pacific sanddab & & & $\mathrm{X}$ & Lumpfishes (NS) & $\mathrm{X}$ & & & & & & \\
\hline Pandalid shrimps (NS) & $\mathrm{X}$ & $\mathrm{X}$ & & Marlin-spike grenadier & & $\mathrm{X}$ & & & & & \\
\hline Octopuses (NS) & $\mathrm{X}$ & $\mathrm{X}$ & & Northern alligatorfish & $\mathrm{X}$ & & & & & & \\
\hline Petrale sole & & & $\mathrm{X}$ & Northern prawn & $\mathrm{X}$ & & & & & & \\
\hline Quillback rockfish & & & $\mathrm{X}$ & Northern sand lance & $\mathrm{X}$ & & & & $\mathrm{X}$ & $\mathrm{X}$ & \\
\hline
\end{tabular}


Table 2 (continued)

\begin{tabular}{|c|c|c|c|c|c|c|c|c|c|c|c|}
\hline & EBS & GOA & HS & & NL & SGOSL & ESS & WSS & GOM & GB & BSNS \\
\hline Rex sole & $\mathrm{X}$ & $\mathrm{X}$ & $\mathrm{X}$ & Ocean pout & & & $\mathrm{X}$ & $\mathrm{X}$ & $\mathrm{X}$ & $\mathrm{X}$ & \\
\hline Rougheye rockfish & $\mathrm{X}$ & $\mathrm{X}$ & & Offshore hake & & & $\mathrm{X}$ & & & & \\
\hline Sablefish & $\mathrm{X}$ & $\mathrm{X}$ & $\mathrm{X}$ & Perciformes & & $\mathrm{X}$ & & & & & \\
\hline Salmon shark & & $\mathrm{X}$ & & Pollock & & & $\mathrm{X}$ & $\mathrm{X}$ & $\mathrm{X}$ & $\mathrm{X}$ & \\
\hline Sand sole & & & $\mathrm{X}$ & Rainbow smelt & & $\mathrm{X}$ & & & & & \\
\hline Sculpins other (NS) & $\mathrm{X}$ & $\mathrm{X}$ & & Red hake & & & $\mathrm{X}$ & $\mathrm{X}$ & $\mathrm{X}$ & $\mathrm{X}$ & \\
\hline Scyphozoid jellies (NS) & $\mathrm{X}$ & & & Rock crab & & $\mathrm{X}$ & $\mathrm{X}$ & & & & \\
\hline Sebastes other (NS) & & $\mathrm{X}$ & & Roughhead grenadier & $\mathrm{X}$ & & & & & & \\
\hline Sharpchin rockfish & & $\mathrm{X}$ & & Roundnose grenadier & $\mathrm{X}$ & & & & & & \\
\hline Shortraker rockfish & & $\mathrm{X}$ & & Saithe & & & & & & & $\mathrm{X}$ \\
\hline Shortspine thornyhead & & $\mathrm{X}$ & & Scorpaeniformes & & $\mathrm{X}$ & & & & & \\
\hline Silvergray rockfish & & & $\mathrm{X}$ & Sculpin & & & $\mathrm{X}$ & $\mathrm{X}$ & & & \\
\hline Sleeper shark & $\mathrm{X}$ & $\mathrm{X}$ & & Sculpins (NS) & $\mathrm{X}$ & & & & & & \\
\hline Slender sole & & & $\mathrm{X}$ & Scup & & & & & $\mathrm{X}$ & $\mathrm{X}$ & \\
\hline Southern rock sole & & $\mathrm{X}$ & $\mathrm{X}$ & Sea raven & $\mathrm{X}$ & $\mathrm{X}$ & & & & & \\
\hline Spotted ratfish & & & $\mathrm{X}$ & Shad & & & $\mathrm{X}$ & & & & \\
\hline Tanner crab & $\mathrm{X}$ & & & Shortfin squid & & $\mathrm{X}$ & & & $\mathrm{X}$ & $\mathrm{X}$ & \\
\hline Walleye pollock & $\mathrm{X}$ & $\mathrm{X}$ & $\mathrm{X}$ & Shorthorn sculpin & & $\mathrm{X}$ & & & & & \\
\hline Yellowfin sole & $\mathrm{X}$ & $\mathrm{X}$ & & Silver hake & & & $\mathrm{X}$ & $\mathrm{X}$ & $\mathrm{X}$ & $\mathrm{X}$ & \\
\hline \multirow[t]{15}{*}{ Yellowtail rockfish } & & & $\mathrm{X}$ & Small pelagics & & & & $\mathrm{X}$ & & & \\
\hline & & & & Smooth dogfish & & & & & & $\mathrm{X}$ & \\
\hline & & & & Snake blenny & $\mathrm{X}$ & & & & & & \\
\hline & & & & Stone crab & & & $\mathrm{X}$ & & & & \\
\hline & & & & Summer flounder & & & & & $\mathrm{X}$ & $\mathrm{X}$ & \\
\hline & & & & Thorny skate & $\mathrm{X}$ & & & & & & \\
\hline & & & & Threebeard rockling (NS) & $\mathrm{X}$ & & & & & & \\
\hline & & & & Threespine stickleback & & $\mathrm{X}$ & & & & & \\
\hline & & & & Toad crabs (NS) & & $\mathrm{X}$ & & & & & \\
\hline & & & & White hake & $\mathrm{X}$ & $\mathrm{X}$ & $\mathrm{X}$ & $\mathrm{X}$ & $\mathrm{X}$ & $\mathrm{X}$ & \\
\hline & & & & Windowpane & & & $\mathrm{X}$ & & $\mathrm{X}$ & $\mathrm{X}$ & \\
\hline & & & & Winter flounder & & $\mathrm{X}$ & $\mathrm{X}$ & & $\mathrm{X}$ & $\mathrm{X}$ & \\
\hline & & & & Witch flounder & $\mathrm{X}$ & $\mathrm{X}$ & $\mathrm{X}$ & & $\mathrm{X}$ & $\mathrm{X}$ & \\
\hline & & & & Wolffishes (NS) & $\mathrm{X}$ & & $\mathrm{X}$ & $\mathrm{X}$ & & & \\
\hline & & & & Yellowtail flounder & & $\mathrm{X}$ & $\mathrm{X}$ & & $\mathrm{X}$ & $\mathrm{X}$ & \\
\hline \multicolumn{12}{|l|}{ Both oceans } \\
\hline Butter sole & & & $\mathrm{X}$ & Butter sole & & & & & & & $\mathrm{X}$ \\
\hline Capelin & $\mathrm{X}$ & $\mathrm{X}$ & & Capelin & $\mathrm{X}$ & $\mathrm{X}$ & & & & & \\
\hline Eelpouts (NS) & $\mathrm{X}$ & $\mathrm{X}$ & & Eelpouts (NS) & $\mathrm{X}$ & $\mathrm{X}$ & & & & & \\
\hline Flatfishes (NS) & $\mathrm{X}$ & $\mathrm{X}$ & & Flatfishes (NS) & & & & $\mathrm{X}$ & & & \\
\hline Greenland halibut & $\mathrm{X}$ & & & Greenland halibut & $\mathrm{X}$ & $\mathrm{X}$ & $\mathrm{X}$ & & & & $\mathrm{X}$ \\
\hline Shrimps (NS) & $\mathrm{X}$ & & & Shrimps (NS) & & $\mathrm{X}$ & & & & & \\
\hline Skates (NS) & $\mathrm{X}$ & $\mathrm{X}$ & $\mathrm{X}$ & Skates (NS) & & $\mathrm{X}$ & $\mathrm{X}$ & $\mathrm{X}$ & $\mathrm{X}$ & $\mathrm{X}$ & \\
\hline Snails (NS) & $\mathrm{X}$ & & & Snails (NS) & $\mathrm{X}$ & & & & & & \\
\hline Snow crab & $\mathrm{X}$ & & & Snow crab & $\mathrm{X}$ & $\mathrm{X}$ & $\mathrm{X}$ & & & & \\
\hline Spiny dogfish & & $\mathrm{X}$ & $\mathrm{X}$ & Spiny dogfish & & $\mathrm{X}$ & $\mathrm{X}$ & $\mathrm{X}$ & $\mathrm{X}$ & $\mathrm{X}$ & \\
\hline Squids (NS) & $\mathrm{X}$ & $\mathrm{X}$ & & Squids (NS) & & & $\mathrm{X}$ & $\mathrm{X}$ & & & \\
\hline
\end{tabular}

Here we assumed that the probability distribution of TLs is normal with the mean being set at the speciesspecific mean TL and coefficient of variation (CV) being set arbitrarily at 0.1 . The mean TL for each species in each ecosystem was obtained either from Ecopath models, if available (Table 1), or from FishBase (Froese \& Pauly 2011). The TL distribution was truncated within an arbitrary range of \pm 0.7 and then scaled by the sum before it was multiplied by the species- and year-specific biomass (see the previous description of data) to distribute the biomass over the range of TLs. For each year from 1984 to 2007, the biomass at each TL interval (0.1) was aggregated over all species to obtain a system biomass-TL spectrum from which absolute cumB-TL curves were obtained. These curves were used to obtain a first 
description of trophic structure modifications in each system through time.

\section{Analysis}

Temporal variations of the total biomass and its distribution among the different TLs within each system was tested by using a Kolmogorov-Smirnov test applied to the absolute curves, allowing us to perform a preliminary assessment of possible modifications in the general curve shape.

In order to improve the comparative analysis, within and among different ecosystems, the raw data were then fitted according to a 4-parameter logistic nonlinear regression model, with the form:

$$
\text { Biomasses }=\frac{A-D}{1+\left(\frac{T L}{C}\right)^{B}}+D
$$

where $A$ and $D$ are the minimum and maximum asymptotes (here set to 0 and 1 , respectively); $B$ is the slope factor/steepness of the curve; and $C$ is the inflection point in terms of TL. The parameters $B$ and $C$ were determined as nonlinear weighted leastsquares estimates of the parameters of the nonlinear model (Bates \& Chambers 1992).

Possible relationships between the temporal trends of curve parameters ( $B$ and $C$ ) and external drivers, such as environmental variables including latitude, sea surface temperature (SST), Pacific Decadal Oscillation (PDO), Siberian/Alaskan Index (SAI), Arctic Oscillation (AO), Atlantic Multidecadal Oscillation (AMO), North Atlantic Oscillation (NAO), chlorophyll a (chl a) and its flux (in terms of sum of anomalies over the year), and fishing pressure, as total catches, were investigated by means of generalized additive models (GAMs; Hastie \& Tibshirani 1990). All drivers are represented by a complete time series (1984-2007), except for the shorter chl a/flux time series (1998-2007). Analyses were carried out for all systems combined and for each individual system independently.

GAMs represent a collection of nonparametric and semi-parametric regression techniques for exploring relationships between response and predictor variables, having greater flexibility for drawing out the long-term nonlinear trends than chain or linear modeling methods. Indeed, some predictors can be modeled non-parametrically, using a cubic spline as the smoothing function, in addition to linear and polynomial terms, allowing the response shape to be fully determined by the data.
The following additive formulation was used:

$$
\mathrm{Y}=\mathrm{a}+s_{1}\left(V_{1}\right)+\ldots+s_{\mathrm{n}}\left(V_{\mathrm{n}}\right)+\varepsilon
$$

where $a$ is the intercept, $s$ is the thin-plate smoothing spline function (Wood 2003), $V_{1} \ldots V_{\mathrm{n}}$ are the predictors, and $\varepsilon$ is the random error. Calculations were carried out using the MGCV package (Wood 2006) in R v 2.13 (R Development Core Team 2011).

The strength of the link between curve parameters and external drivers was assessed by quantifying the probability density distribution of the correlation coefficients obtained by bootstrap resampling. This analysis involved a random pairwise sampling with replacement where each time series was resampled 5000 times. The number of elements in each bootstrap sample equals the number of elements in the original dataset. The probability density distribution of the corresponding correlation coefficients was then computed using nonparametric kernel smoothing (Casini et al. 2010).

\section{RESULTS}

The absolute cumB-TL curves for each system are reported in Fig. 1. The analysis of temporal trends of the total biomass highlighted different patterns in different regions (Table 3), but, in spite of different characteristics of each system, a consistent pattern both in terms of geographical areas and latitudes emerged. The Pacific systems (EBS, GOA, HS) showed a decreasing total biomass trend over time, though less pronounced in the Gulf of Alaska (GOA). The western Atlantic systems (GB, GOM, WSS, ESS, SGOSL, NL) showed different patterns in relation to latitude, with a decreasing biomass in the higher latitude systems (WSS, ESS, SGOSL, NL) and either an increasing or a fluctuating pattern in the lower ones (GB, GOM). The eastern Atlantic system (BSNS) showed a consistently increasing pattern. In all systems, with the exception of the GOA, differences between the extremes of the curves were statistically significant (Kolmogorov-Smirnov test; Table 3), confirming a modification of the curve shape during the period analyzed.

In order to better describe the observed temporal trends, steepness $(B)$ and TL inflection points $(C)$ of each curve were estimated (Figs. $2 \& 3$ ). Differences highlighted in the absolute curve analyses were also reflected in the analyses of steepness and inflection point parameters of the relative curves, as can be seen for the within-system estimates of the standard deviation of $B$ (Table 4 ). 

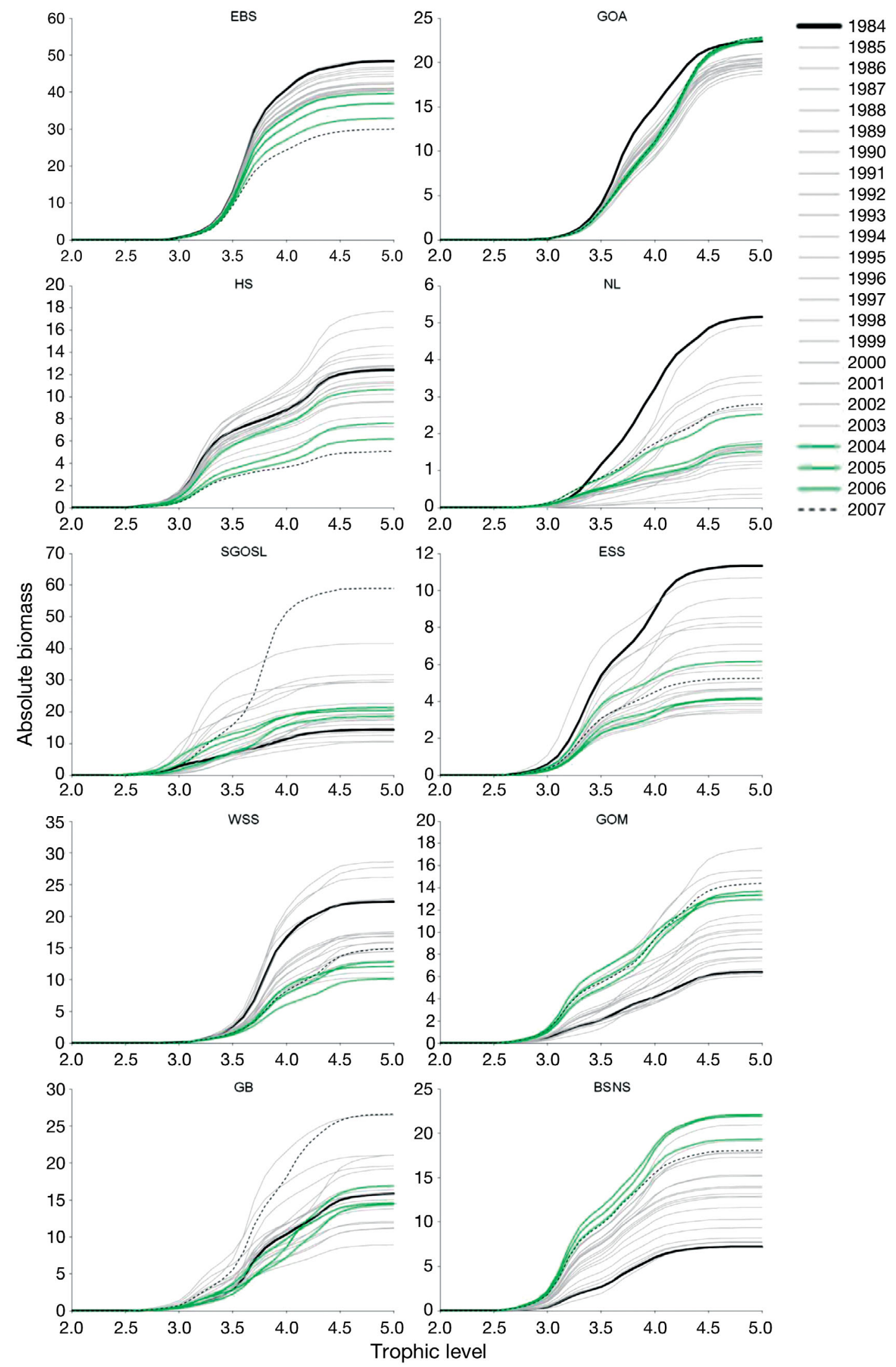

Fig. 1. Absolute cumulative biomass-trophic level curves. Ecosystem abbreviations as in Table 1 
Table 3. Temporal evolution analysis of the absolute cumulative biomass-trophic level curves in different years for each study system; years used in the test are shown in parentheses. Ecosystem abbreviations as in Table 1

\begin{tabular}{|c|c|c|c|}
\hline Ecosyster & Trend & $\begin{array}{l}\text { Kolmogorov-Smirnov test } \\
\text { p (years) }\end{array}$ & Notes \\
\hline EBS & Decreasing & $0.005(1986-2007)$ & 2007 the lowest value \\
\hline GOA & Slightly decreasing (stable) & $>0.1$ & Pattern quite stable \\
\hline HS & Decreasing & $<0.001(1989-2007)$ & 2007 the lowest value \\
\hline NL & Mixed & $<0.05(1984-2007)$ & $\begin{array}{l}1984 \text { the highest value, the early 1990s the lowest } \\
\text { (when the collapse was recorded, see Table1) }\end{array}$ \\
\hline SGOSL & Mixed & $<0.001(1998-2007)$ & 2007 the highest value, but a generally stable pattern \\
\hline ESS & Decreasing & $<0.001(1984-2007)$ & 2003 the lowest value, then a partial recovery \\
\hline WSS & Decreasing & $<0.01(1986-2004)$ & 2004 the lowest value \\
\hline GOM & Increasing & $<0.001(1987-2002)$ & 2002 the highest value, 1987 the lowest \\
\hline GB & Mixed & $<0.025(1984-2007)$ & 2001 and 2007 the highest values, mid-1990s the lowest \\
\hline BSNS & Increasing & $<0.001(1984-2007)$ & $\begin{array}{l}\text { A constant increasing trend, } 2005 \text { the highest value, } \\
1986 \text { the lowest }\end{array}$ \\
\hline
\end{tabular}

The time series of $B$ and $C$ allowed for the exploration of the role that external drivers, such as environmental parameters and fishing pressure, have on the TL of systems. The analysis of all systems combined (both without and with the chl $a$, which is represented by a shorter time series) highlighted that SST, latitude, chl a (when considered), and fishery (landings) all played an important role in shaping the cumB-TL curves, whereas the other atmospheric parameters had minimal to no influence (Figs. 4 to 7 ; Table 5). Latitude and fishery showed contrasting effects: increasing latitude decreased the steepness of the cumB-TL curve and the inflection point to shift towards higher TL, whereas increasing fishing pressure resulted in an increase of the steepness and a reduction of the TL inflection point, as would be expected. In contrast, chl a and SST positively affected both parameters. The general pattern holds when ecosystems were analyzed individually except that SST was replaced by regional atmospheric

Table 4. Mean values of curve parameters (average 19842007), obtained by fitting raw data; $B$ : steepness; $C$ : trophic level inflection point (see Eq. 1). Ecosystem abbreviations as in Table 1

\begin{tabular}{|lrrcc|}
\hline & mean $B$ & SD & mean $C$ & SD \\
\hline EBS & 38.49 & 10.65 & 3.56 & 0.01 \\
GOA & 17.58 & 4.42 & 3.90 & 0.05 \\
HS & 13.51 & 0.76 & 3.65 & 0.05 \\
NL & 9.09 & 4.88 & 3.49 & 0.27 \\
SGOSL & 30.79 & 31.51 & 3.42 & 0.11 \\
ESS & 25.74 & 28.43 & 3.54 & 0.21 \\
WSS & 32.03 & 38.71 & 3.73 & 0.12 \\
GOM & 18.71 & 2.58 & 3.76 & 0.06 \\
GB & 38.52 & 33.19 & 3.73 & 0.05 \\
BSNS & 25.47 & 1.69 & 3.65 & 0.03 \\
\hline
\end{tabular}

indices (Table 6); the AMO and PDO, often coupled with the fishing pressure, were significantly correlated with the curve parameters.

\section{DISCUSSION}

We assert that the results shown here represent a fundamental feature of marine ecosystems. In either absolute or relative curves, the accumulation of biomass is a consistent feature across a wide range of ecosystems characterized by distinctive taxa and as influenced by distinct drivers. This is consistent with prior studies that have examined size spectra (Jennings et al. 2002b, Piet \& Jennings 2005) or food web model outputs (Link et al. 2009a, Pranovi \& Link 2009). That we consistently observed a sigmoidal relationship, with the highest accumulation of biomasses at middle TLs, is not a trivial finding. The resultant pattern was robust both in terms of the

Table 5. Correlation between parameters of the cumulative biomass-trophic level curves and external drivers (only parameters showing significant relationships are reported). The analysis was carried out for all systems combined with and without the chlorophyll a $(\mathrm{chl}$ a)/flux chl a time series. + : significant positive relationship ${ }_{i}-$ : significant negative relationship. SST: sea surface temperature; AMO: Atlantic Multidecadal Oscillation; TC: Total catches

\begin{tabular}{|ccccccc|}
\hline Parameter & SST & AMO & Latitude & Chl a & TC \\
\hline All systems & & & & & \\
Steepness & + & & - & Without & + \\
Inflection & + & - & + & Without & - \\
All systems & & & & & \\
Steepness & & & - & + & + \\
Inflection & & & + & + & - \\
\hline
\end{tabular}




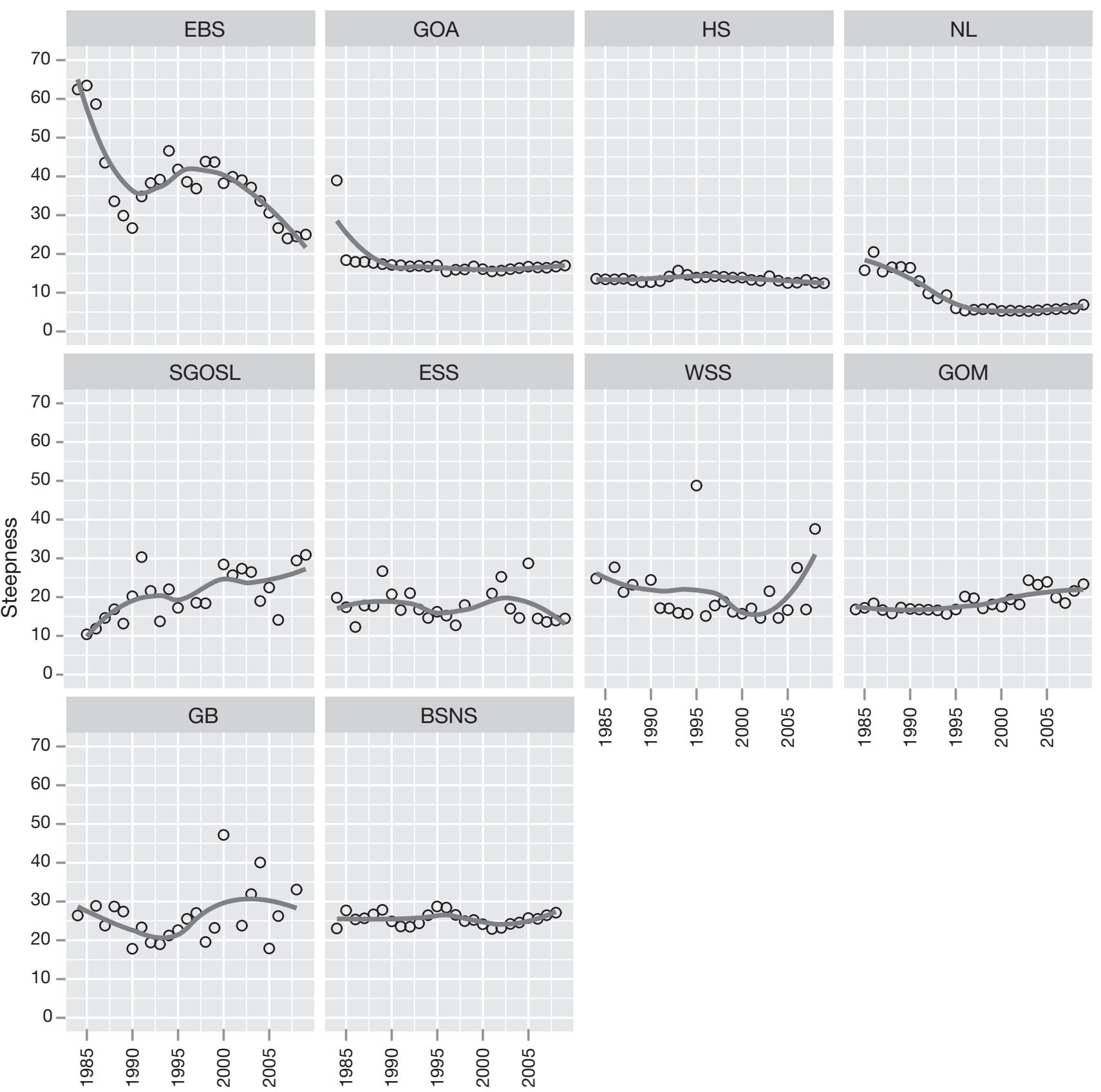

Fig. 2. Steepness (B) time series (see Eq. 1), for each analyzed ecosystem. Ecosystem abbreviations as in Table 1

methodology applied to construct the trophic spectra and the taxonomical composition of the analyzed database, resulting in the fact that it is not a simple property of the fish community (see also Link et al. 2009a). One could readily leverage this fundamental feature of marine ecosystems to both further elucidate ecosystem dynamics and establish systemic management thresholds.

In terms of absolute curves, the dynamics of the emergent pattern also seem to be consistent both in terms of the geographic area and latitude of the analyzed systems. Higher-latitude systems (both in the Pacific and Atlantic) exhibit a decrease in total biomass over time, whereas mid-latitude systems (in both the Eastern and Western Atlantic) exhibited an increase or at least a fluctuating trend. These dynamics represent a change in realized production and may be indicative of structural shifts in lower TL community structure in response to broad-scale phenomena (see, for example, changes recorded in the 


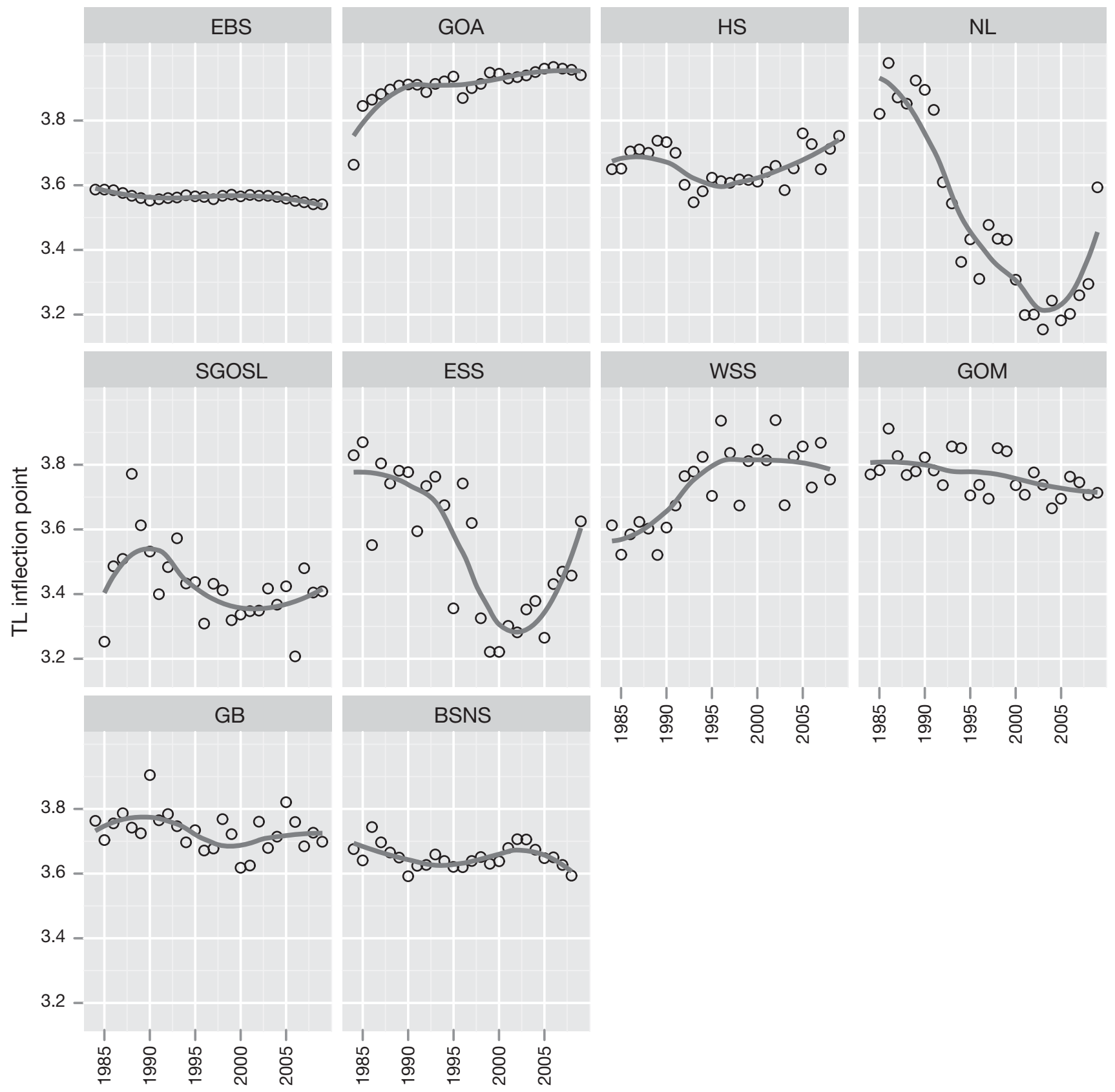

Fig. 3. Trophic level inflection point $(C)$ time series (see Eq. 1), for each analyzed ecosystem. Ecosystem abbreviations as in Table 1

Newfoundland-Labrador system, Table 1). Suggestions of this have been implied in prior studies (Drinkwater et al. 2009, Gaichas et al. 2009, Link et al. 2009b, 2010a, Megrey et al. 2009, Pranovi \& Link 2009, Blanchard et al. 2010, Coll et al. 2010).

The relative curves exhibit lower biomass accumulation for higher-latitude systems, which are reflected in a lower steepness and consequently a higher TL inflection point. This observation may be a result of the somewhat lower primary productivity of those high-latitude systems, although on an areal basis and as annually integrated, some of those higher latitude systems can be quite productive (Gaichas et al. 2009, Lucey et al. 2012, this TS) and have supported significant fisheries production (Mueter \& Megrey 2006, Link et al. 2009b, Bundy et al. 2012, this TS). That there are differences in ecosystems across latitudes is not surprising; what is surprising is the minimal difference between ocean basins. 

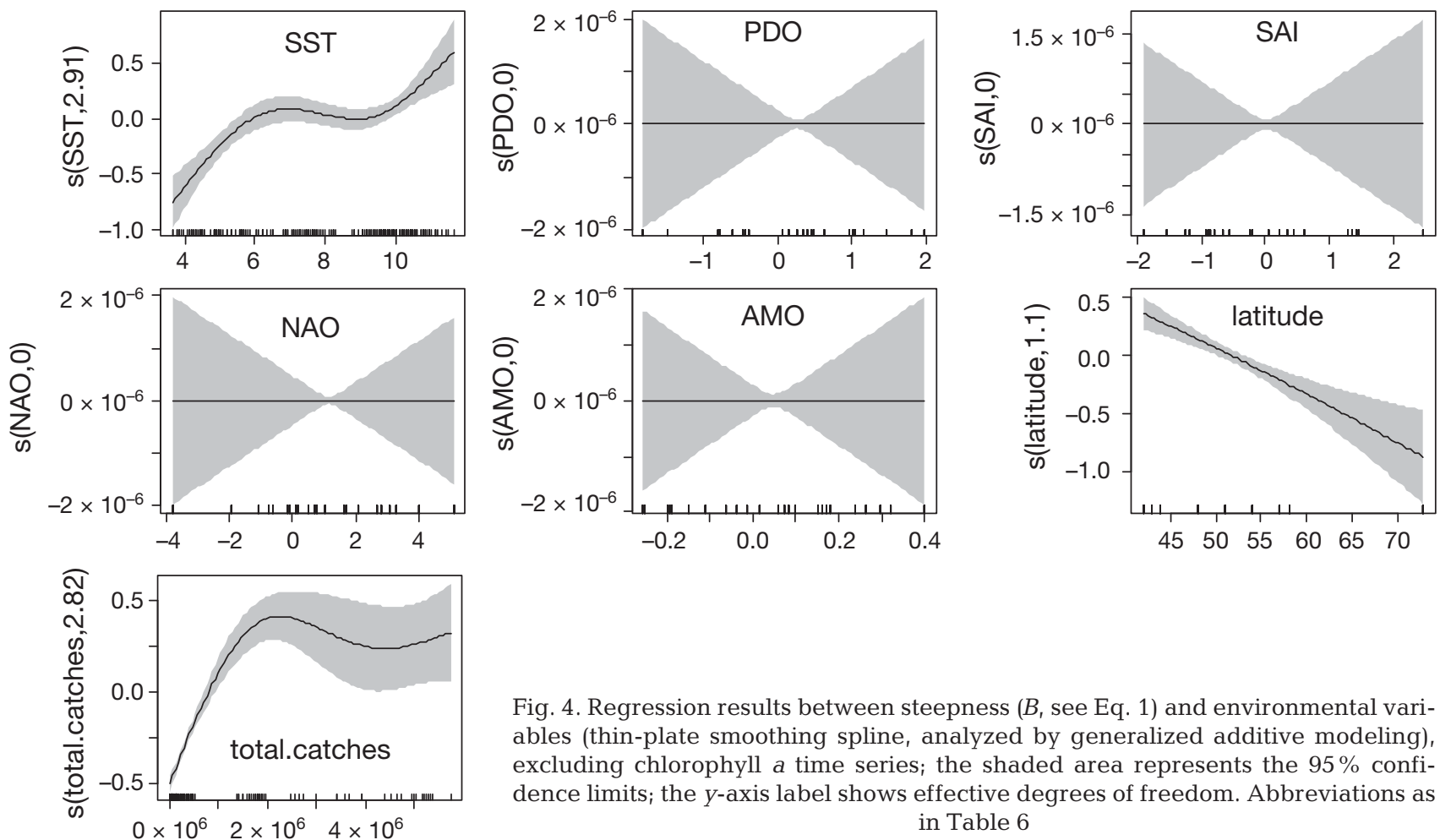

Fig. 4. Regression results between steepness ( $B$, see Eq. 1) and environmental variables (thin-plate smoothing spline, analyzed by generalized additive modeling), excluding chlorophyll a time series; the shaded area represents the $95 \%$ confidence limits; the $y$-axis label shows effective degrees of freedom. Abbreviations as in Table 6
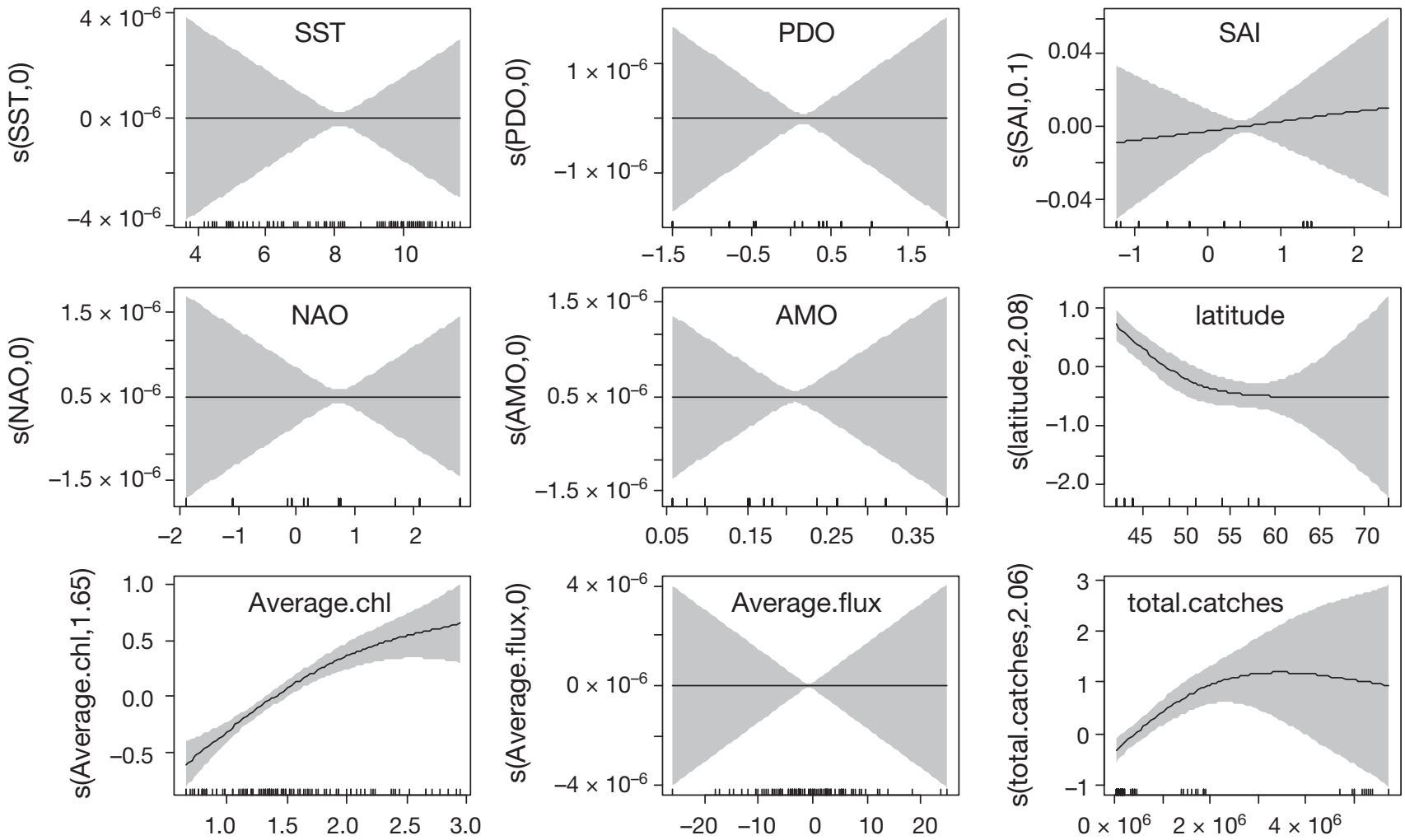

Fig. 5. Regression results between steepness $(B)$ and environmental variables (thin-plate smoothing spline, analyzed by generalized additive modeling), including chlorophyll a time series; the shaded area represents the $95 \%$ confidence limits; the $y$-axis label shows effective degrees of freedom. Abbreviations as in Table 6 

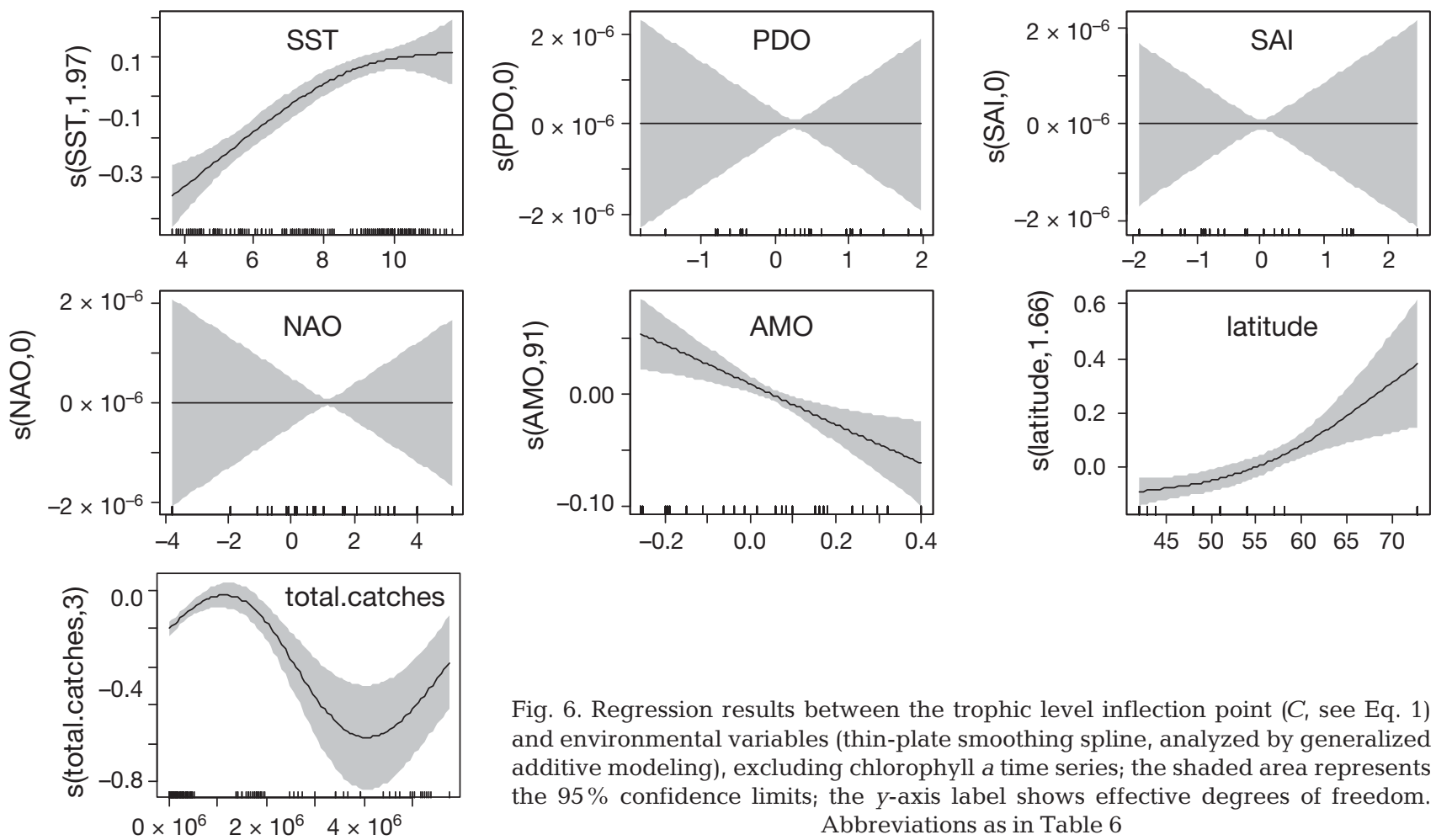

Fig. 6. Regression results between the trophic level inflection point $(C$, see Eq. 1$)$ and environmental variables (thin-plate smoothing spline, analyzed by generalized additive modeling), excluding chlorophyll a time series; the shaded area represents the $95 \%$ confidence limits; the $y$-axis label shows effective degrees of freedom. Abbreviations as in Table 6
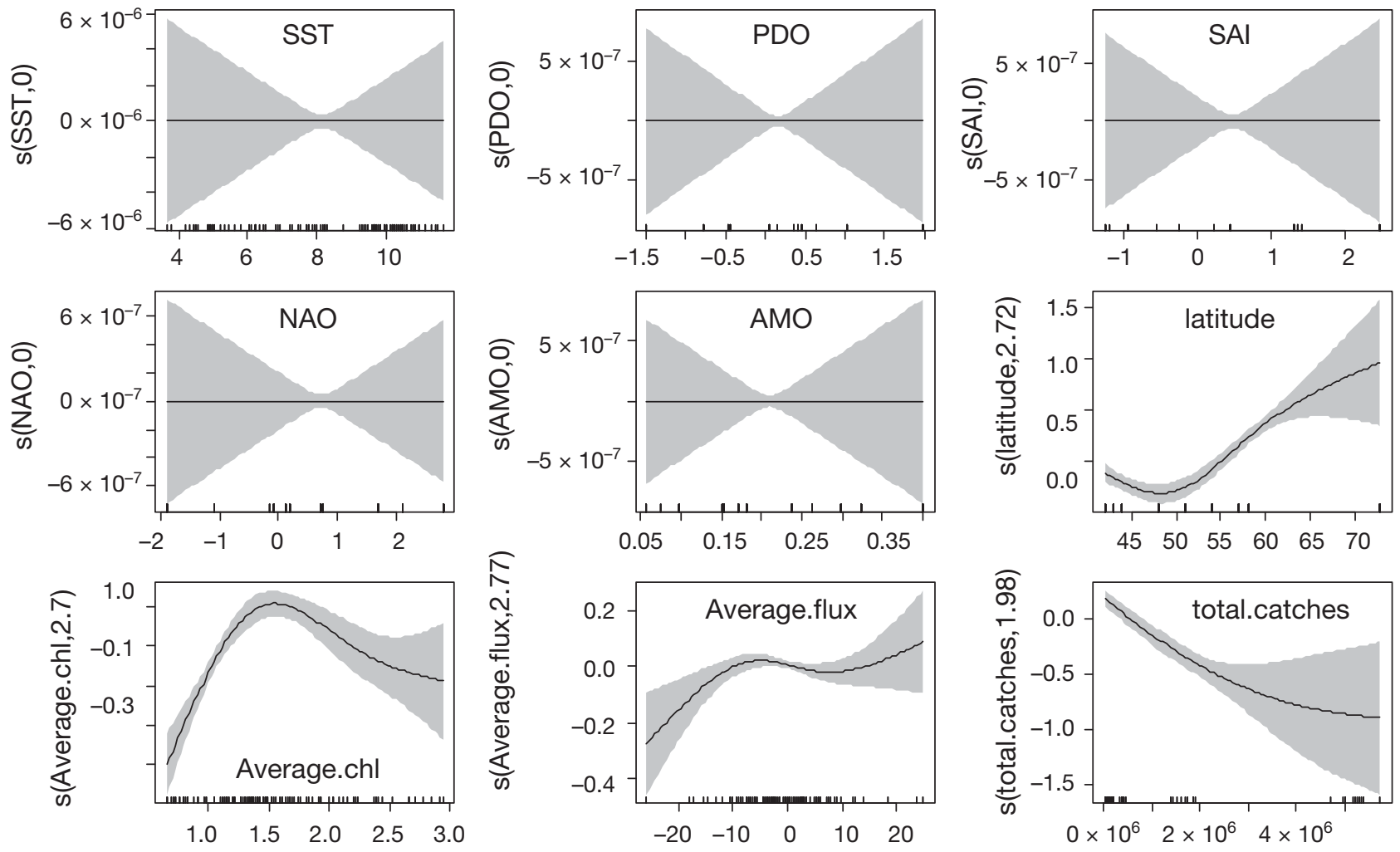

Fig. 7. Regression results between the trophic level inflection point $(C)$ and environmental variables (thin-plate smoothing spline, analyzed by generalized additive modeling), including chlorophyll a time series; the shaded area represents the $95 \%$ confidence limits; the $y$-axis label shows effective degrees of freedom. Abbreviations as in Table 6 
Table 6. Correlation between parameters of the cumulative biomass-trophic level curves and external drivers (only systems/ parameters showing significant relationships are reported), with analysis carried out on individual systems. +: significant positive relationship; -: significant negative relationship; ( ): almost significant $(0.1>p>0.05)$; \pm : significant relationship inverse U-shaped. Ecosystem abbreviations as in Table 1. SST: sea surface temperature, PDO: Pacific Decadal Oscillation, SAI: Siberian/Alaskan Index; AO: Arctic Oscillation; NAO: North Atlantic Oscillation; AMO: Atlantic Multidecadal Oscillation

\begin{tabular}{|c|c|c|c|c|c|c|c|c|}
\hline System & Parameter & SST & PDO & SAI & $\mathrm{AO}$ & $\mathrm{NAO}$ & $\mathrm{AMO}$ & Total catches \\
\hline EBS & Steepness & & + & & & & & \\
\hline \multirow[t]{2}{*}{ GOA } & Steepness & & + & $(+)$ & + & & & + \\
\hline & Inflection & & & & & & & - \\
\hline GB & Steepness & & & & & & & - \\
\hline GOM & Inflection & & & & & & - & \pm \\
\hline \multirow[t]{2}{*}{ SGOSL } & Steepness & & & & & & + & \\
\hline & Inflection & & & & & & & + \\
\hline \multirow[t]{2}{*}{ NL } & Steepness & & & & & & - & + \\
\hline & Inflection & & & & & & $(-)$ & + \\
\hline \multirow[t]{2}{*}{ ESS } & Steepness & + & & & & & & \\
\hline & Inflection & & & & & & - & $(+)$ \\
\hline \multirow[t]{2}{*}{ WSS } & Steepness & & & & & + & & \\
\hline & Inflection & & & & & & - & - \\
\hline BSNS & Inflection & - & & & & & & + \\
\hline
\end{tabular}

If these cumB-TL curves and their associated parameters are to be used as potential indicators of EOF, their relation to the major triad of drivers needs to be established. Across all of the ecosystems we examined, measures of exploitation can influence the curves, producing a consistent pattern, with an increase of steepness at lower exploitation levels and then a decrease at higher levels and a downward shift in the TL inflection point. This could be related on one hand to a direct effect of fishing activities on higher TLs, exporting biomass from the system, thereby producing a reduction in TL. This could also be combined with predation release whereby decreases in higher TL fish results in less predation on those at lower TLs, which in turn increase, thereby lowering the mean TL (Benoît \& Swain 2008). On the other hand, exploitation can indirectly affect higher TLs by reducing the energy flowing from the lower TLs when the exploitation targets lower TL species, such as forage fish (Gascuel et al. 2008, Libralato et al. 2008). Either way, the resulting change in the curve would be a flatter profile with a lower total biomass. These results are consistent with the pattern reported by Sosa-López et al. (2005), who described a flattening of biomass cumulative curves in relation to an increase of anthropogenic impacts.

Environmental metrics are also related to the features of the relative cumulative biomass curves. On a global scale, taking into the account all of the systems, both an increase in SST and chl a resulted in a downward shift in the inflection point and an increase in steepness, thereby making the cumB-TL curves more pronounced. This does not directly im- ply the presence of a positive relationship between the 2 environmental parameters, since this issue is still debated (see also Chavez et al. 2011 and Friedland et al. 2012), but simply indicates the possible presence of a similar mechanism driving the ecological processes, in relation to both SST and chl a. The positive effect of chl a on the cumB-TL curve shape is in agreement with very recent findings by Friedland et al. (2012).

In the individual ecosystem based analysis, patterns in the cumB-TL curves over time confirmed a strong effect of fishing pressure on the structure and functioning of the system, as was also shown in the global-scale analysis. This is seen via an effect of fishing on the TL inflection point and a flattening out of the curve (reflected in the lower steepness values). At this level of analysis, moreover, SST is replaced by atmospheric variables as the significant environmental driver. AMO (which almost always had negative effects) played a significant role in the Atlantic systems and PDO (always positive effects) in the Pacific systems, although the same pattern of the cumB-TL curves is seen. Both results confirm the observations regarding the key environmental influences (as reported in Table 1 ).

Collectively across systems, within systems, and considering both exploitation and environmental effects, what our results show is that positive ecosystem responses are exhibited as a 'stretching' or heightening of the sigmoidal curves. Conversely, negative effects on an ecosystem are exhibited as a flattening of these sigmoidal curves (Fig. 8). An example from our analysis is the flattening of the 
Fig. 8. Conceptual diagram illustrating (A) expected variations in the cumulative biomass-trophic level (cumB-TL) curve shape in relation to external drivers; (B) effects on the absolute curves; (C) effects on the relative curve

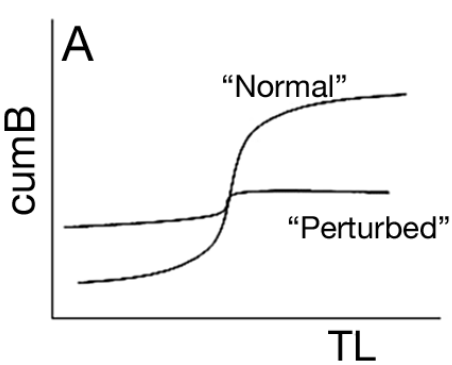

TL
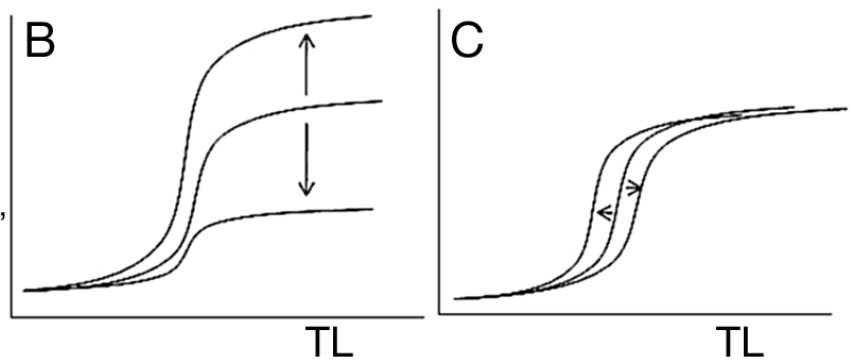

curves in the NL system due to the collapse recorded in the 1990s. A corollary would be that as ecosystems are degraded, their patterns on these curves would flatten out, but as they recover their patterns would be clearly demonstrable. Examples from our analyses show that the GOM, NSBS, and GB ecosystems exhibited some recovery in fishery resources, which has been confirmed by more detailed studies on the component species in those ecosystems (Drinkwater et al. 2009, Link et al. 2009b).

Thus, this fundamental sigmoid feature could potentially be used as a system-level biological reference point of EOF. For instance, as changes occurred in a given ecosystem, the inflection point and steepness parameters also reflected those changes, indicative of potential system-level thresholds similar to other attempts to define ecosystem overfishing (Tudela et al. 2005, Coll et al. 2008, 2010, Libralato et al. 2008, Link et al. 2010a, Shin et al. 2010a). The value of this approach is that it is a relatively simple derivation of readily available survey data and does not require extensive multi-species, food web, or ecosystem modeling, other than to obtain reasonable values for TL. Indeed, while in the previous application (Link et al. 2009a) the cumB-TL method was applied to an extensive multi-species food web database, in the present study it was applied to data from surveys or assessments.

By establishing the cumB-TL curves and then calculating steepness and inflection parameters, a robust set of 2 simple metrics could be monitored to detect when a shift in community structures was beyond normal ranges of the data. Clearly further work is warranted on developing methodological features (e.g. sensitivity to the TL attribution could be a critical issue) and establishing probabilistic thresholds, but as a first-order attempt to examine EOF from an empirically-based, trophodynamic perspective, this approach holds some promise.

Obviously, some caveats have to be taken into the account. Giving a picture of the state of the ecosystem, in the present version the method requires for comparison at least 2 different temporal points, in order to assess the direction of changes. Moreover, as previously shown, there could be different external drivers which produce similar effects on the cumBTL curve shape; for this reason, some cautions are required in determining causes of a detected change.

Robust ecological indicators of the trophic structure of marine communities, and long-term changes therein, are now available (Sosa-López et al. 2005). The sigmoidal relationship of cumB-TL curves is another possible indicator, among many in development (Libralato et al. 2008, Coll et al. 2008, Link et al. 2009a, 2010a, Shannon et al. 2010, Shin et al. 2010a), that could be used to delineate EOF. Moving towards fuller implementation of EBFM will necessarily require a suite of robust indicators. We trust that what we propose here is a useful step towards that end as these ecological indicators continue to develop.

Acknowledgements. This collaborative, multilateral work was funded through the US Comparative Analysis of Marine Ecosystem Organization (CAMEO), the Norwegian Research Council (NRC), and Canada's Ecosystem Research Initiative (ERI). Major national institutes (Fisheries and Oceans Canada, Institute for Marine Research of Norway, and the US National Marine Fisheries Service) also made significant in-kind contributions and directed resources to this project. This work is also endorsed by Ecosystem Studies of Sub-Arctic Seas (ESSAS). The work we report upon herein resulted from several joint meetings, particularly the Surplus Production Modeling Workshop (SPMW 1 \& 2) and associated inter-sessional efforts, representing a continuation of and follow-up to other joint workshops, including Canadian and US Ecosystems (CANUSE I \& II), Marine Ecosystems of Norway and the US (MENU I \& II), and Norwegian-Canadian Collaborations (NORCAN). Finally, we dedicate this work to the memory of Bern Megrey, who was an integral part of these efforts and whose untimely death was unfortunate but whose enthusiasm for this work was invaluable.

\section{LITERATURE CITED}

Ainsworth C, Heymans JJ, Pitcher TJ, Vasconcellos M (2002) Ecosystem models of northern British Columbia for the time periods 2000, 1950, 1900 and 1750. Fish Cent Res Rep 10(4):1-41

Araújo JN, Bundy A (2011) Description of three Ecopath 
with Ecosim ecosystem models developed for the Bay of Fundy, Western Scotian Shelf and NAFO Division 4X. Can Tech Rep Fish Aquat Sci 2952:1-189

Aydin K, Gaichas S, Ortiz I, Kinzey D, Friday N (2007) A comparison of the Bering Sea, Gulf of Alaska, and Aleutian Islands large marine ecosystems through food web modeling. NOAA Tech Memo NMFS-AFSC-178. US Department of Commerce, NOAA, NMFS, Woods Hole, MA

Bates DM, Chambers JM (1992) Nonlinear models. In: Chambers JM, Hastie TJ (eds) Statistical models. Wadsworth \& Brooks/Cole, Pacific Grove, CA, p 421-453

Benoît HP, Swain DP (2008) Impacts of environmental change and direct and indirect harvesting effects on the dynamics of a marine fish community. Can J Fish Aquat Sci 65:2088-2104

Blanchard JL, Coll M, Trenkel VM, Vergnon R and others (2010) Trend analysis of indicators: a comparison of recent changes in the status of marine ecosystems around the world. ICES J Mar Sci 67:732-744

> Bozec YM, Kulbicki M, Chassot E, Gascuel D (2005) Trophic signature of coral reef fish assemblages: towards a potential indicator of ecosystem disturbance. Aquat Living Resour 18:103-109

Bundy A (2005) Structure and functioning of the eastern Scotian Shelf ecosystem before and after the collapse of groundfish stocks in the early 1990s. Can J Fish Aquat Sci 62:1453-1473

> Bundy A, Shannon LJ, Rochet MJ, Neira S, Shin YJ, Hill L, Aydin K (2010) The good(ish), the bad and the ugly: a tripartite classification of ecosystem trends. ICES J Mar Sci 67:745-768

Bundy A, Bohaboy EC, Hjermann DO, Mueter FJ, Fu C, Link JS (2012) Common patterns, common drivers: comparative analysis of aggregate surplus production across ecosystems. Mar Ecol Prog Ser 459:203-218

- Casini M, Bartolino V, Molinero JC, Kornilovs G (2010) Linking fisheries, trophic interactions and climate: threshold dynamics drive herring Clupea harengus growth in the central Baltic Sea. Mar Ecol Prog Ser 413:241-252

Chavez FP, Messiè M, Pennington JT (2011) Marine primary production in relation to climate variability and change. Annu Rev Mar Sci 3:227-260

> Coll M, Libralato S, Tudela S, Palomera I, Pranovi F (2008) Ecosystem overfishing in the ocean. PLoS ONE 3:e3881

Coll M, Shannon LJ, Yemane D, Link JS and others (2010) Ranking the ecological relative status of exploited marine ecosystems. ICES J Mar Sci 67:769-786

> Cury PM, Christensen V (2005) Quantitative ecosystem indicators for fisheries management. ICES J Mar Sci 62: 307-310

> Degnbol P, Jarre A (2004) Review of indicators in fisheries management - a development perspective. Afr J Mar Sci 26:303-326

Drinkwater KF, Mueter F, Friedland KD, Taylor M, Hunt JL Jr, Hare J, Melle W (2009) Recent climate forcing and physical oceanographic changes in Northern Hemisphere regions: a review and comparison of four marine ecosystems. Prog Oceanogr 81:10-28

Friedland KD, Stock C, Drinkwater KF, Link JS and others (2012) Pathways between primary production and fisheries yields of large marine ecosystems. PLoS ONE 7: e28945

Froese F, Pauly D (eds) (2011) FishBase. www.fishbase.org

> Fu C, Gaichas S, Link JS, Bundy A and others (2012) Relative importance of fisheries, trophodynamic and environ- mental drivers in a series of marine ecosystems. Mar Ecol Prog Ser 459:169-184

- Gaichas S, Skaret G, Falk-Petersen J, Link JS and others (2009) A comparison of community and trophic structure in five marine ecosystems based on energy budgets and system metrics. Prog Oceanogr 81:47-62

> Gascuel D, Bozec Y, Chassot E, Colomb A, Laurans M (2005) The trophic spectrum: theory and application as an ecosystem indicator. ICES J Mar Sci 62:443-452

> Gascuel D, Morissette L, Palomares MLD, Christensen V (2008) Trophic flow kinetics in marine ecosystems: toward a theoretical approach to ecosystem functioning. Ecol Model 217:33-47

Hastie T, Tibshirani R (1990) Generalized additive models in S. Chapman \& Hall, London

Holling CS, Schindler DW, Walker B, Roughgarden J (1995) Biodiversity in the functioning of ecosystems: an ecological primer and synthesis. In: Perring C, Mäer KG, Folke C, Holling CS, Jansson BO (eds) Biodiverity loss: ecological and economic issues. Cambridge University Press, Cambridge

- Jennings S, Warr KJ, Mackinson S (2002a) Use of size-based production and stable isotope analyses to predict trophic transfer efficiencies and predator-prey body mass ratios in food webs. Mar Ecol Prog Ser 240:11-20

Jennings S, Greenstreet S, Hill L, Piet G, Pinnegar J, Warr KJ (2002b) Long-term trends in the trophic structure of the North Sea fish community: evidence from stable-isotope analysis, size-spectra and community metrics. Mar Biol 141:1085-1097

Libralato S, Solidoro C (2010) Comparing methods for building trophic spectra of ecological data. ICES J Mar Sci 67: 426-434

Libralato S, Coll M, Tudela S, Palomera I, Pranovi F (2008) Novel index for quantification of ecosystem effects of fishing as removal of secondary production. Mar Ecol Prog Ser 355:107-129

> Link JS (2005) Translating ecosystem indicators into decision criteria. ICES J Mar Sci 62:569-576

Link JS, Griswold C, Methratta EM, Gunnard J (eds) (2006) Documentation for the Energy Modeling and Analysis eXercise (EMAX). Ref Doc 06-15. Northeast Fisheries Science Center, Woods Hole, MA

Link JS, Overholtz W, O'Reilly J, Green J and others (2008) The Northeast U.S. continental shelf Energy Modeling and Analysis exercise (EMAX): ecological network model development and basic ecosystem metrics. J Mar Syst 74:453-474

Link JS, Pranovi F, Coll M, Libralato S, Christensen V, Legault C (2009a) Exploring novel metrics of ecosystem overfishing using energy budget model outputs. Fish Cent Res Rep 17(3):153

> Link JS, Stockhausen W, Skaret G, Overholtz W and others (2009b) A comparison of biological trends from four marine ecosystems: synchronies, differences, and commonalities. Prog Oceanogr 81:29-46

Link JS, Yemane D, Shannon LJ, Coll M, Shin YJ, Hill L, de Fatima Borges M (2010a) Relating marine ecosystem indicators to fishing and environmental drivers: an elucidation of contrasting responses. ICES J Mar Sci 67: $787-795$

> Link JS, Megrey BA, Miller TJ, Essington T and others (2010b) Comparative analysis of marine ecosystems: international production modelling workshop. Biol Lett $6: 723-726$ 
Link, JS, Gaichas S, Miller TJ, Essington T and others (2012) Synthesizing lessons learned from comparing fisheries production in 13 northern hemisphere ecosystems: emergent fundamental features. Mar Ecol Prog Ser 459: 293-302

Lucey SM, Cook AM, Boldt JL, Link JS, Essington TE, Miller TJ (2012) Comparative analyses of surplus production dynamics of functional feeding groups across 12 northern hemisphere marine ecosystems. Mar Ecol Prog Ser 459:219-229

Megrey BA, Hare J, Dommasnes A, Gjøsæter H and others (2009) A cross-ecosystem comparison of spatial and temporal patterns of covariation in the recruitment of functionally analogous fish stocks. Prog Oceanogr 81:63-92

Morissette L, Despatie SP, Savenkoff C, Hammill MO, Bourdages H, Chabot D (2003) Data gathering and input parameters to construct ecosystem models for the northern Gulf of the St. Lawrence (mid-1980's). Can Tech Rep Fish Aquat Sci 2497:1-100

> Mueter FJ, Megrey BA (2006) Maximum productivity estimates for the groundfish complexes of the Gulf of Alaska and Eastern Bering Sea / Aleutian Islands. Fish Res 81: 189-201

Murawski SA, Steele JH, Taylor P, Fogarty MJ, Sissenwine MP, Ford M, Suchman C (2009) Why compare marine ecosystems? ICES J Mar Sci 67:1-9

Odum WE, Heald EJ (1975) The detritus-band foodweb on an estuarine mangrove community. In: Cronin LE (ed) Estuarine research. Academic Press, New York, NY, p 265-286

Pauly D, Christensen V, Walters C (2000) Ecopath, Ecosim, and Ecospace as tools for evaluating ecosystem impact of fisheries. ICES J Mar Sci 57:697-706

Piatt JF, Sydeman WJ, Wiese F (2007) Introduction: seabirds as indicators of marine ecosystems. Mar Ecol Prog Ser 352:199-204

Piet G, Jennings S (2005) Response of potential fish community indicators to fishing. ICES J Mar Sci 62:214-225

Pitcher T, Cochrane K (2002) The use of ecosystem models to investigate multispecies management strategies for capture fisheries. Fish Cent Res Rep 10(2):1-156

Submitted: October 19, 2011; Accepted: March 28, 2012
Pitcher TJ, Heymans JJ, Vasconcellos M (2002) Ecosystem models of Newfoundland for the time periods 1995, 1985, 1900 and 1450. Fish Cent Res Rep 10(5):1-76

Pranovi F, Link JS (2009) Ecosystem exploitation and trophodynamic indicators: a comparison between the Northern Adriatic Sea and Southern New England. Prog Oceanogr 81:149-164

R Development Core Team (2011) R: a language and environment for statistical computing. $\mathrm{R}$ Foundation for Statistical Computing, Vienna. Available at www.Rproject.org

Rice JC, Rochet MJ (2005) A framework for selecting a suite of indicators for fisheries management. ICES J Mar Sci 62:516-527

Shannon LJ, Coll M, Yemane D, Jouffre D and others (2010) Comparing data-based indicators across upwelling and comparable systems for communicating ecosystem states and trends. ICES J Mar Sci 67:807-832

Shin YJ, Shannon LJ, Bundy A, Coll M and others (2010a) Using indicators for evaluating, comparing, and communicating the ecological status of exploited marine ecosystems. 2. Setting the scene. ICES J Mar Sci 67:692-716

> Shin YJ, Bundy A, Shannon LJ, Simier M and others (2010b) Can simple be useful and reliable? Using ecological indicators to represent and compare the states of marine ecosystems. ICES J Mar Sci 67:717-731

Skaret G, Pitcher TJ (2012) An ecosystem model of the Norwegian Sea and Barents Sea fitted to data. Fish Cent Res Rep (in press)

> Sosa-López A, Mouillot D, Chi TD, Ramos-Miranda J (2005) Ecological indicators based on fish biomass distribution along trophic levels: an application to the Terminos coastal lagoon, Mexico. ICES J Mar Sci 62:453-458

Tudela S, Coll M, Palomera I (2005) Developing an operational reference framework for fisheries management on the basis of a two-dimensional index of ecosystem impact. ICES J Mar Sci 62:585-591

> Wood SN (2003) Thin-plate regression splines. J R Stat Soc B Stat Methodol 65:95-114

Wood SN (2006) Generalized additive models: an introduction with R. Chapman and Hall/CRC, Boca Raton, FL

Proofs received from author(s): June 29, 2012 